\title{
MODIFIKASI ALAT TANGKAP RAJUNGAN (Portunus pelagicus) DALAM MENINGKATKAN HASIL TANGKAPAN NELAYAN
}

\section{MODIFICATION OF CRAB'S FISHING DEVICE (Portunus pelagicus) IN INCREASING THE FISHERMAN PRODUCTION}

\author{
Irnawati1), Subari Yanto2), dan Jamaluddin. P3). \\ ${ }^{1}$ Alumni Program Studi Pendidikan Teknologi Pertanian \\ ${ }^{2}$ dan ${ }^{3}$ Dosen PTP FT UNM \\ irnawati1innha23@gmail.com
}

\begin{abstract}
ABSTRAK
Penelitian ini bertujuan untuk memodifikasi alat tangkap rajungan (Portunus pelagicus) dalam meningkatkan jumlah dan produksi tangkapan nelayan. Jumlah alat tangkap yang digunakan sebanyak 10 buah terdiri dari 5 alat tangkap sesudah modifikasi dan 5 alat tangkap sebelum modifikasi. Penelitian ini merupakan penelitian rancang bangun. Data diambil dengan menggunakan analisis deskriptif dan analisis perbandingan. Hasil penelitian menunjukkan bahwa jumlah tangkapan tertinggi pada trip pertama sebanyak 10 ekor dan jumlah tangkapan tertinggi pada trip kedua sebanyak 7 ekor, sedangkan produksi tangkapan tetinggi selama 2 trip penangkapan sebanyak $627 \mathrm{~g}$.

Kata Kunci : Modifikasi, Alat Tangkap, Rajungan, Nelayan
\end{abstract}

\section{ABSTRACT}

This study aimed to modify the crab's fishing device (Portunus pelagicus) in increasing the production of the fisherman. The number of fishing tools was 10 pieces, consists of 5 tools after the modification and 5 tools beforer the modification. This research is a design building. The data was collected through descriptive analysis and comparison analysis. The result of the research stage showed that on the first trip the highest number of catches crab is 10 tails and the second trip the highest number of catches crab is 7 tails, while the highest production of crab during 2 trip is $627 \mathrm{~g}$.

Keywords: Modification, Fishing Device, Crabs, Fisherman.

\section{PENDAHULUAN}

Perikanan merupakan salah satu aktivitas yang memberikan kontribusi terhadap kesejahteraan suatu bangsa. Kabupaten Pangkajene dan Kepulauan atau yang lebih dikenal dengan nama Kabupaten Pangkep yang terletak di wilayah pantai barat Sulawesi Selatan, memiliki luas wilayah keseluruhan sebesar 12.362,73 $\mathrm{km}^{2}$ dengan luas wilayah laut sebesar $11.464,44 \mathrm{~km}^{2}$.
Salah satu potensi perikanan yang ada di kabupaten Pangkep adalah rajungan.Desa Pitusunggu kecamatan Ma'rang kabupaten Pangkep merupakan salah satu wilayah penghasil rajungan yang cukup tinggi. Desa pitusunggu memiliki kelompok industri nelayan rajungan.

Rajungan (Portunus pelagicus) merupakan salah satu komoditas perikanan yang memiliki nilai ekonomis yang cukup tinggi (Balai Bimbingan dan 
Pengujian Mutu Hasil Perikanan (BPPMHP) 2000) dan merupakan komoditas ekspor yang permintaannya dari tahun ke tahun semakin meningkat. Sampai saat ini, seluruh kebutuhan ekspor rajungan masih mengandalkan dari hasil penangkapan di laut, sehingga di khawatirkan akan mempengaruhi jumlah populasinya di alam (Amtoni $d k k$, 2010).

Menurut Amtoni (2010) penggunaan alat tangkap yang tidak ramah lingkungan mendorong terjadinya eksploitasi yang berlebihan terhadap sumberdaya perikanan, tidak terkecuali rajungan. Kecenderungan masyarakat nelayan untuk memaksimalkan hasil tangkapan dengan menggunakan alat tangkap yang tidak ramah lingkungan seperti arad dan garok rajungan akan menimbulkan permasalahan terhadap penurunan stok diperairan.

Alat tangkap yang digunakan oleh nelayan rajungan adalah perangkap yang mempunyai satu atau dua pintu masuk dan dapat diangkat ke beberapa daerah penangkapan dengan mudah, dengan atau tanpa perahu.Alat tangkap rajungan adalah alat tangkap yang sangat efektif untuk menangkap organisme yang bergerak lambat di dasar perairan, baik laut maupun danau. (Dollu, A. E, 2013).

Alat tangkap rajungan pada umumnya masih menggunakan pintu masuk rajungan hanya 2 buah.Alat tangkap rajungan dengan penerapan 2 pintu masuk memiliki peranan yang sangat penting khususnya bagi nelayan rajungan. Nelayan rajungan memerlukan alat tangkap yang banyak pada saat pengoperasiannya, namun tidak memiliki alat tangkap yang cukup banyak dikarenakan kurangnya biaya.Untuk menghemat dan mengefesienkan penggunaan alat tangkap, diperlukan inovasi baru yaitu memodifikasi alat tangkap rajungan dengan menambahkan 2 pintu masuk sehingga memiliki 4 buah pintu masuk rajungan.

Alat tangkap yang sudah dimodifikasi memiliki keungulan yaitu memiliki 4 pintu masuk (multi pintu) sehingga peluang rajungan untuk masuk menjadi lebih besar apabila dibandingkan dengan alat tangkap sebelumnya yang hanya memiliki dua pintu. Alat tangkap yang dimodifikasi mengunakan prinsip knock down yaitu alat tangkap yang bisa di lepas/di buka apabila sudah di operasikan dan bisa di pasang kembali ketika akan melakukan operasi penangkapan, mudah dalam perawatan sehingga tidak mudah rusak, terbuat dari bahan dasar yang tahan terhadap air laut sehingga dapat terus bertahan dalam jangka waktu yang lama, dan apabila rusak dapat diperbaiki dan biaya untuk perbaikan tidak terlalu mahal, hasil tangkapan diharapkan banyak karena alat tangkap yang dimodifikasi menggunakan empat pintu masuk, pada saat pengoperasian nelayan tidak perlu sampai ikut menyelam untuk mengatur posisi alat tangkap, saat pengoperasian nelayan dapat membawa alat tangkap dalam jumlah yang banyak, dan menggunakan pelampung sebagai pelampung tanda. Penelitian ini dilakukan di desa Pitusunggu kecamatan Ma'rang kabupaten Pangkep povinsi Sulawesi Selatan.

\section{TUJUAN PENELITIAN}

Tujuan yang ingin dicapai dalam penelitian ini adalah : Meningkatkan jumlah tangkapan nelayan rajungan dan meningkatkan berat (g) produksi rajungan 


\section{METODE PENELITIAN}

Bentuk penelitian ini adalah penelitian rancang bangun. Penelitian ini dimulai dari perencanaan membuat desain gambar serta kebutuhankebutuhan untuk perakitan alat.

Alat dan bahan yang digunakan dalam perancangan alat, yaitu mistar siku, kikir, tali, tang, kamera, timbangan, alat tulis menulis, besi, jaring throwl

Penentuan daerah penangkapan alat tangkap rajungan didasarkan pada tempat sejauh $2 \mathrm{~km}$ dari daratan Desa Pitusunggu Kecamatan Ma'rang Kabupaten Pangkejene dan Kepulauan dengan kedalaman $20 \mathrm{~m}$ dan berdasarkan pengalaman nelayan.Uji coba produk pada penelitian ini dilakukan dengan cara sebagai berikut:

1. Melakukan persiapan operasi penangkapan. Pengoperasian alat dilakukan selama 2 trip ( 2 Minggu)

2. Mengoperasikan alat tangkap dengan cara dirangkai pada satu tali utama (long line traps), jumlah alat tangkap yang digunakan sebanyak 10 buah yaitu 5 alat sebelum modifikasi yang di beri simbol $A$ yaitu A1, A2, A3, A4 dan A5 dan 5 alat sesudah modifikasi yang di beri simbol B yaitu B1, B2, B3, B4 dan B5. Pemberian simbol alat tangkap bertujuan untuk memudahkan dalam membedakan alat tangkap sebelum dan sesudah modifikasi yang digunakan dan penomoran simbol berfungsi sebagai nomor urut setiap jenis alat tangkap. Dengan jarak antar tali alat tangkap sejauh $5 \mathrm{~m}$ dan ujung tali alat tangkap di beri pelampung.

3. Penurunan alat tangkap dilakukan pada sore hari dengan menghabiskan waktu 1 jam yaitu pukul 15.00-16.00 Wita.
4. Perendaman (Immersing) alat tangkap dilakukan selama 13 jam yaitu dari pukul $16.00-05.00$ Wita

5. Penarikan dilakukan pada pukul 05.00 Wita. Penarikan alat membutuhkan waktu 2 jam. Setelah alat tangkap ditarik maka diambil hasil tangkapannya.

6. Kemudian dilakukan penghitungan kapasitas alat tangkap berdasarkan jumlah dan berat produksi tangkapan.

\section{Hasil Uji Coba}

\section{Pengoperasian Alat Trip Pertama}

a. Jumlah dan Berat Tangkapan

Pengoperasian alat trip pertama dilakukan untuk menangkap rajungan selama 7 hari (pertama).Parameter yang diamati adalah jumlah dan berat hasil tangkapan.Berikut ini merupakan hasil uji coba mengenai pengoperasian alat pada trip petama.

\section{1) Jumlah Tangkapan}

Jumlah tangkapan merupakan jumlah yang dihasilkan oleh 2 jenis alat yang digunakan. Jumlah tangkapan rajungan dengan menggunakan alat tangkap rajungan sebelum dan sesudah modifikasi pada pengoperasian alat trip pertama dapat dilihat pada Gambar 1. 


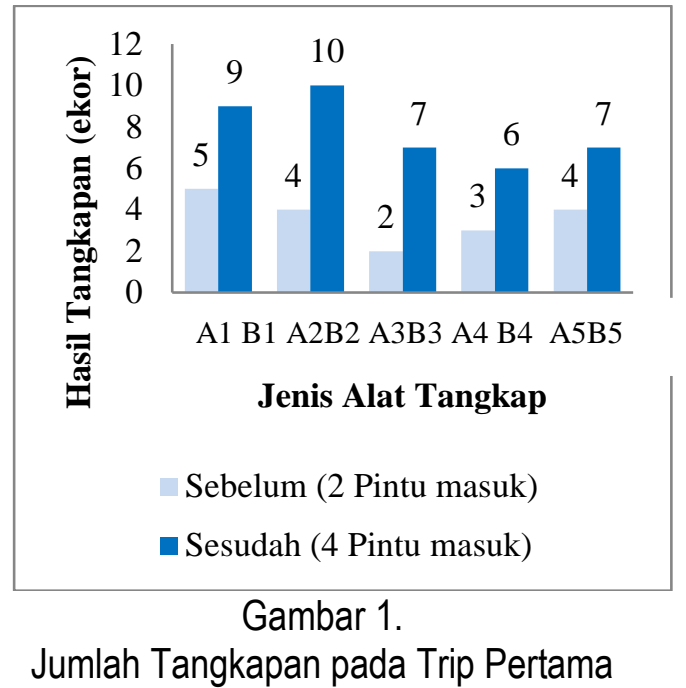

Jumlah tangkapan dengan 2 jenis alat tangkap pada pengoperasian alat trip pertama menunjukkan bahwa jumlah tangkapan tertinggi pada alat tangkap sebelum modifikasi terdapat pada alat tangkap A1 dan jumlah tangkapan terendah terdapat pada alat tangkap A3. Sedangkan jumlah tangkapan tertinggi pada alat tangkap sesudah modifikasi terdapat pada alat tangkap B2 jumlah tangkapan dan jumlah tangkapan terendah terdapat pada alat tangkap B4.

Rata-rata jumlah tangkapan alat sebelum dan dan sesudah modifikasi pada pengoperasian alat trip pertama dapat dilihat pada Gambar 2.

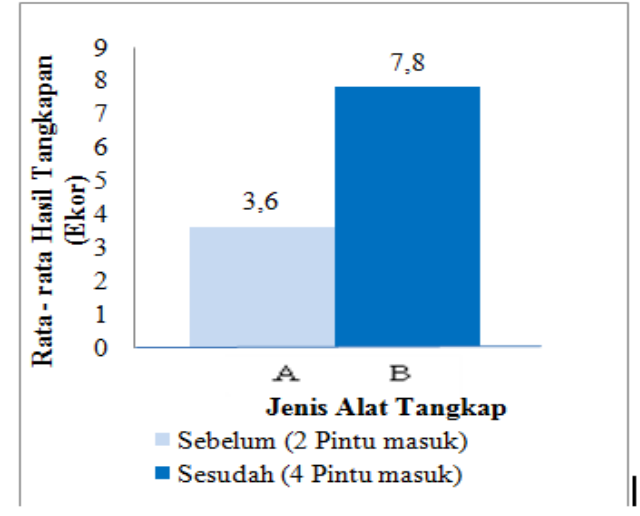

Gambar 2.

Rata-rata Jumlah Tangkapan pada Trip Pertama
Rata-rata jumlah tangkapan pada trip pertama dengan penggunaan alat sebelum dan sesudah modifikasi menunjukkan bahwa rata- rata jumlah tangkapan tertinggi terdapat pada penggunaan alat $B$ dan rata-rata jumlah tangkapan terendah terdapat pada penggunaan alat $A$.

\section{2) Berat Tangkapan}

Berat tangkapan merupakan berat yang dihasilkan dari 2 jenis alat tangkap. Berat tangkapan alat tangkap rajungan sebelum dan sesudah modifikasi pada pengoperasian alat alat trip pertama dapat dilihat pada Gambar 3.

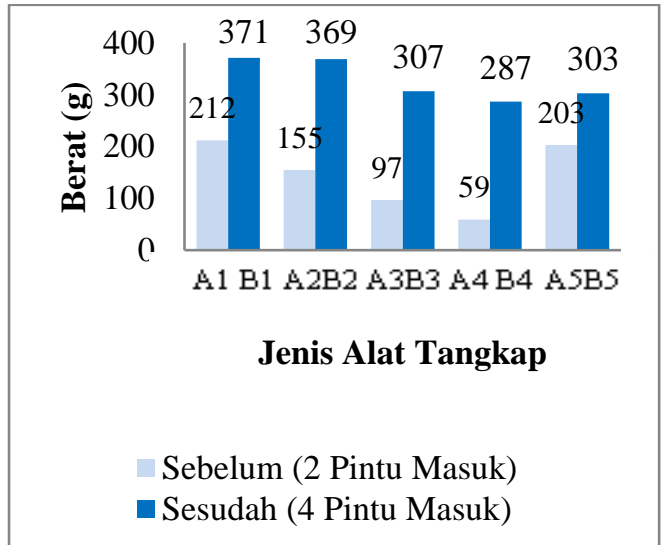

Gambar 3.

Berat Hasil Tangkapan pada Trip Pertama

Berat hasil tangkapan dengan 2 jenis alat tangkap pada pengoperasian alat trip pertama menunjukkan bahwa berat hasil tangkapan tertinggi pada alat tangkap sebelum modifikasi terdapat pada alat tangkap A1 dan berat hasil tangkapan terendah terdapat pada alat tangkap A4. Sedangkan berat hasil tangkapan tertinggi pada alattangkap sesudah modifikasi terdapat pada alat tangkap B1 yaitu dan berat hasil tangkapan terendah terdapat pada alat tangkap B4. 
Rata- rata berat hasil tangkapan alat sebelum dan dan sesudah modifikasi pada pengoperasian alat trip pertama dapat dilihat pada Gambar 4.

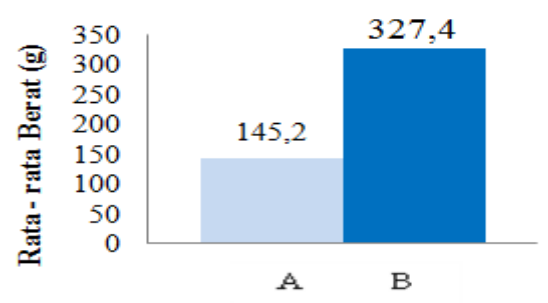

Jenis Alat Tangkap

\begin{tabular}{l}
$\quad$ Sebelum (2 Pintu Masuk) \\
$\quad$ Sesudah (4 Pintu Masuk) \\
\hline
\end{tabular}

Gambar 4.

Rata-rata Berat Tangkapan pada Trip

Pertama

Rata-rata berat hasil tangkapan pada trip pertama dengan penggunaan alat sebelum dan sesudah modifikasi menunjukkan bahwa rata-rata berat hasil tangkapan tertinggi terdapat pada penggunaan alat $B$ dan rata-rata berat hasil tangkapan terendah terdapat pada penggunaan alat $A$.

\section{Pengoperasian Alat trip Kedua}

a. Jumlah dan Berat Tangkapan

Pengoperasian alat trip kedua dilakukan untuk menangkap rajungan selama 7 hari (kedua).Parameter yang diamati adalah jumlah dan berat hasil tangkapan.Berikut ini merupakan hasil uji coba mengenai pengoperasian alat pada trip kedua.

1) Jumlah Tangkapan

Jumlah tangkapan merupakan jumlah yang dihasilkan oleh 2 jenis alat yang digunkan. Jumlah tangkapan rajungan dengan menggunakan alat tangkap rajungan sebelum dan sesudah modifikasi pada pengoperasian trip kedua dapat dilihat pada Gambar 5.

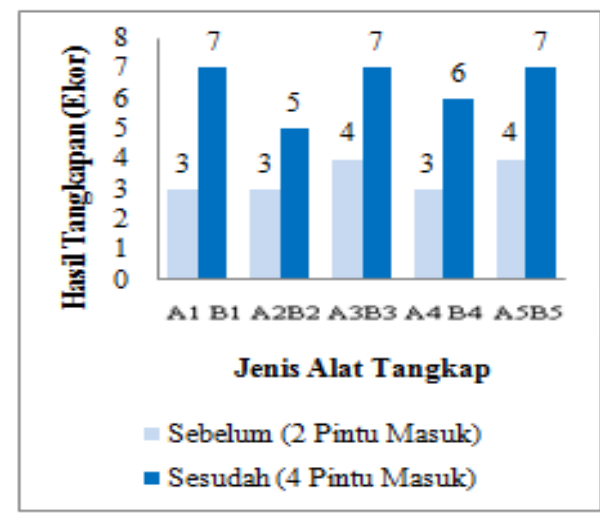

Gambar 5.

Jumlah Tangkapan pada Trip Kedua

Jumlah tangkapan dengan 2 jenis alat tangkap pada pengoperasian alat trip kedua menunjukkan bahwa jumlah tangkapan tertinggi pada alat tangkap sebelum modifikasi terdapat pada alat tangkap A3 dan A5 dan jumlah tangkapan terendah terdapat pada alat tangkap A1, A2 dan A4. Sedangkan jumlah tangkapan tertinggipada alat tangkap sesudah modifikasi terdapat pada alat tangkap B1, B3 dan B5 dan jumlah tangkapan terendah terdapat pada alat tangkap B2.

Rata-rata jumlah tangkapan alat sebelum dan dan sesudah modifikasi pada pengoperasian alat trip kedua dapat dilihat pada Gambar 6 .

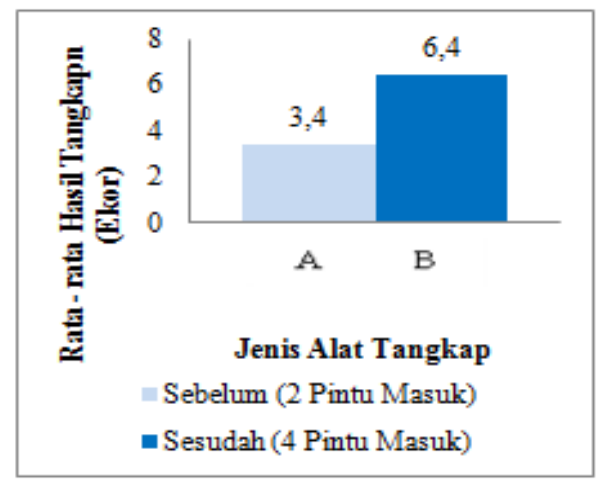

Gambar 6.

Rata - Rata Jumlah Tangkapan pada

Trip Kedua 
Rata-rata jumlah tangkapan pada trip kedua dengan penggunaan alat sebelum dan sesudah modifikasi menunjukkan bahwa rata-rata jumlah tangkapan tertinggi terdapat pada penggunaan alat $B$ dan rata-rata jumlah tangkapan terendah terdapat pada penggunaan alat $A$.

\section{2) Berat Tangkapan}

Berat tangkapan merupakan berat yang dihasilkan dari 2 jenis alat tangkap. Berat tangkapan alat tangkap rajungan sebelum dan sesudah modifikasi pada pengoperasian alat trip kedua dapat dilihat pada Gambar 7.

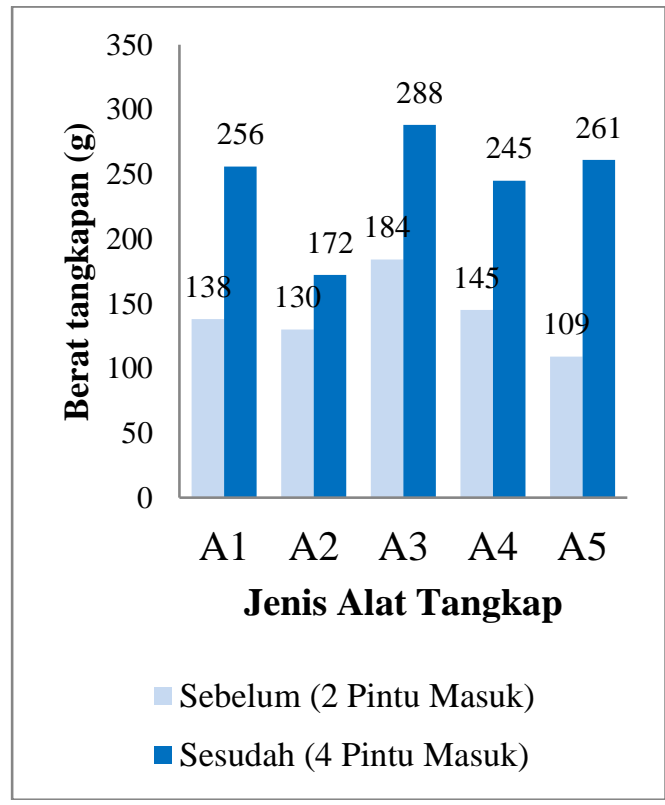

Gambar 7.

Berat Tangkapan Jumlah Tangkapan pada Trip Kedua

Berat hasil tangkapan dengan 2 jenis alat tangkap pada pengoperasian alat trip kedua menunjukkan bahwa berat hasil tangkapan tertinggi pada alat tangkap sebelum modifikasi terdapat pada alat tangkap A3 dan berat hasil tangkapan terendah terdapatpada alat tangkap A5. Sedangkan berat hasil tangkapan tertinggi pada alat tangkap sesudah modifikasi terdapat pada alat tangkap B3 dan berat hasil tangkapan terendah terdapat pada alat tangkap B2.

Rata-rata berat hasil tangkapan alat sebelum dan dan sesudah modifikasi pada pengoperasian alat trip pertama dapat dilihat pada Gambar 8.

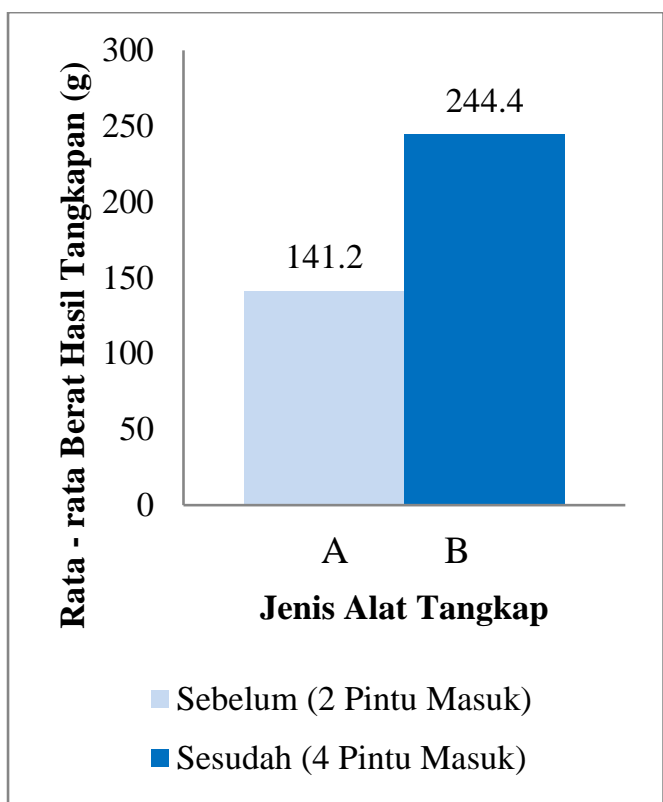

Gambar 8.

Rata-rata Berat Tangkapan Trip Kedua

Rata-rata berat hasil tangkapan pada trip pertama dengan penggunaan alat sebelum dan sesudah modifikasi menunjukkan bahwa rata-rata berat hasil tangkapan tertinggi terdapat pada penggunaan alat $B$ dan rata-rata berat hasiltangkapan terendah terdapat pada penggunaan alat $A$.

\section{Produksi Rajungan}

Produksi rajungan merupakan jumlah totalhasil tangkapan tangkapan dalamkurung waktu 2 trippenangkapan. Parameter yang diamati adalah produksi tangkapan. Berikut ini merupakan hasil uji coba mengenai produksi rajungan. 


\section{a. Produksi Tangkapan}

Produksi tangkapan merupakan berat yang dihasilkan dari 2 jenis alat tangkap. Produksi tangkapan alat tangkap rajungan sebelum dan sesudah modifikasi pada pengoperasian alat selama 2 trip penangkapan dapat dilihat pada Gambar 9.

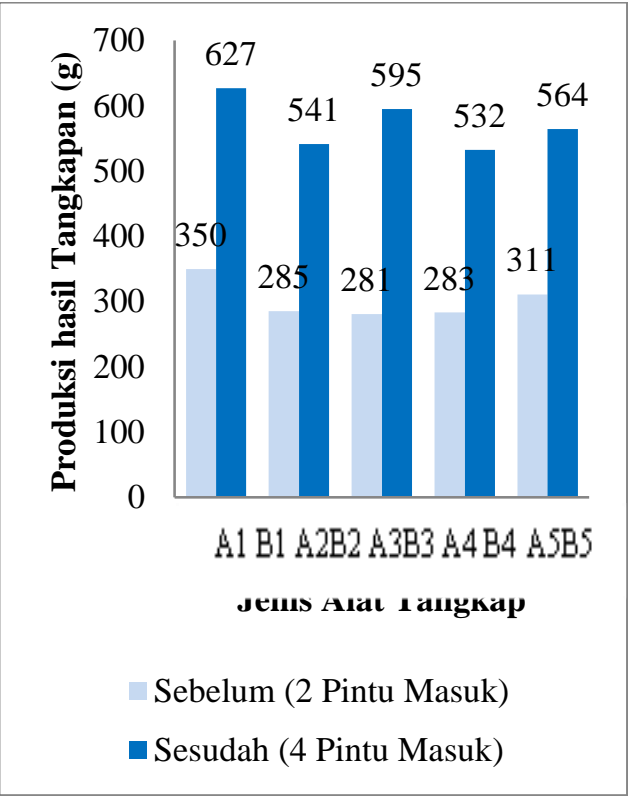

Gambar 9.

Produksi Tangkapan Trip Pertama dan Trip Kedua

Produksi tangkapan selama 2 trip penangkapan dengan 2 jenis alat tangkap pada pengoperasian alat menunjukkan bahwa produksi tangkapan tertinggi pada alat tangkap sebelum modifikasi terdapat pada alat tangkap A5 dan produksi tangkapan terendah terdapat pada alat tangkap A3. Sedangkan produksi tangkapan tertinggi pada alat tangkap sesudahmodifikasi terdapat pada alat tangkap B1 dan produksi angkapan terendah terdapat pada alat tangkap B4.

Rata-rata produksi tangkapan pada pengoperasian alat selama 2 trip penangkapan dapat dilihat pada Gambar 10.

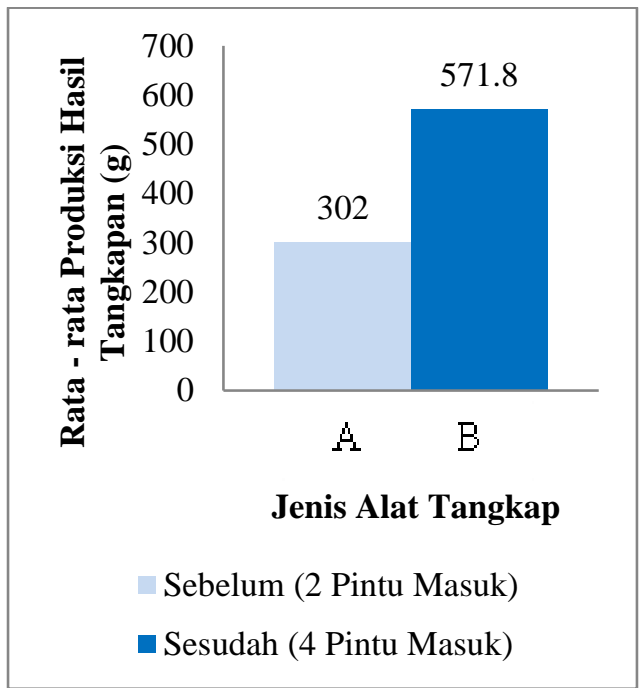

Gambar 10.

Rata - rata Produksi Hasil Tangkapan

Rata-rata produksi tangkapan selama 2 trip penangkapan dengan penggunaan alat sebelum dan sesudah modifikasi menunjukkan bahwa rata-rata produksi tangkapan tertinggi terdapat pada penggunaan alat $B$ dan rata-rata produksi tangkapan terendah terdapat pada penggunaan alat $A$.

Berdasarkanjumlah tangkapan yang dihasilkan oleh alat tangkap sebelum dan sesudah modifikasi mengalami fluktuasi. Hal ini dapat disebabkan oleh beberapa faktor diantaranya, ketersediaan rajungan, factor cuaca, kondisi perairan dan juga penempatan alat tangkap (Pradenta, dkk. 2014 : 37 - 45).Sesuai dengan yang diungkapkan oleh Tiyoso (1979) menyatakan bahwa fluktuasi hasil tangkapan dari alat tangkap jenis bubu terjadi karena:

1) Migrasi dan perubahan harian, musiman, maupun tahunan dalam kelompok ikan

2) Keragaman ukuran ikan dalam populasi

3) Tepat tidaknya penentuan tempat pemasangan bubu, 
karena alat tangkap jenis ini bersifat pasif.

Cahaya bulan baru dan bulan purnama mempengaruhi hasil tangkapan rajungan yaitu terkait dengan kondisi pencahayaan dan fluktuasi pasang surut. Sesuai dengan penenlitian yang dilakukan oleh Nishida et. al (2006) yang mengemukakan bahwa fluktuasi pasang surut dapat mempengaruhi siklus hidup, aktivitas dan distribusi hewan - hewan yang hidup di perairan pantai, termasuk hewan - hewan yang bersifat benthik. Perubahan tingkah laku dan aktivitas dari hewan - hewan tersebut mempengaruhi strategi penangkapan dalam kegiatan perikanan tangkap. Selain berpengaruh terhadap fluktuasi pasang surut air laut, siklus bulan juga berpengaruh terhadap intensitas cahaya dan lama penyinaran sehingga mempengaruhi aktivitas organisme perairan.

Jumlah dan berat hasil tangkapan pada pengoperasian alat trip pertama lebih besar dibanding jumlah dan berat hasil tangkapan pada pengoperasian alat trip kedua. Salah satu faktor yang dapat mempengaruhi adalah fase bulan baru dan fase bulan purnama. Berdasarkan penelitian yang dilakukan oleh Ernawati (2013) yang mengemukakan bahwa pada fase purnama, intensitas cahay optimum mampu menembus cahaya perairan pada perairan yang lebih dalam hingga dasar perairan pada perairan dangkal tentu akan memudahkan rajungan untuk mencari makan.

Alat tangkap yang digunakan menggunakan umpan ikan mati. Ikan adalah salah satu makanan yang disukai oleh rajungan setelah crustase dan molusca (Josileen, 2011). Rajungan hidup di dasar laut untuk mencari makan dan sebagai karnivora maupun pemakan bangkai (scavengers) (Sumpton, 1993).
Pada fase purnama dan bulan baru terjadi pasang tertinggi, pada kondisi tersebut distribusi mangsa dan makanan di kolom perairan melimpah (Robinson dan Gomez, A, 2004) sehingga banyak rajungan yang berenang menuju kolom perairan (vertical migratory). Setelah air pasang mulai surut rajungan kembali ke dasar perairan. Saat rajungan kembali ke dasar perairan peluang untuk masuk ke bubu (dianggap sebagai tempat perlindungan) lebih besar sehingga rajungan banyak yang tertangkap (Ernawati, 2013).

Perbedaan konstruksi alat tangkap 2 pintu dengan 4 pintu akan menghasilkan perbedaan jumlah tangkapan, sesuai dengan penilitian yang dilakukan oleh lismawati (2005) dengan membandingkan bubu karang serang dan bubu pelabuhan ratu yang mengemukakan bahwa hasil yang diperoleh antara kedua jenis bubu tidak mengakibatkan perubahan variasi hasil tangkapan.

Apabila penangkapan dilakukan dengan konstruksi alat yang berbeda maka besar kemungkinan hasil tangkapan akan berbeda pula. Hal ini sesuai dengan penilitian yang dilakukan oleh Stergiou et al. (2002) yang mengatakan bahwa hasil tangkapan antara jenis alat tangkap gillnet dan longline berbeda, padahal kedua alat tersebut dioperasikan pada daerah penangkapan yang sama. Dan sesuai dengan pengamatan Miller (1995) yaitu tentang faktor pembatas masuknya kepiting dalam bubu. Faktor tersebut adalah ukuran bubu, bentuk bubu, lokasi penangkapan, bahan konstruksi mulut masuk dan celah pelolosan.

Berdasarkan berat tangkapan alat sebelum dan sesudah modifikasi menghasilkan berat rajungan yang bervariasi. Hal ini diduga karena terdapat 
perbedaan konstruksi alat sebelum modifikasi lebih kecil dan memiliki 2 pintu dibandingan dengan alat tangkap sesudah modifikasi yang memiliki ukuran yang lebih besar dan memiliki 4 pintu. Berdasarkan penelitian yang dilakukan oleh Muldiani (2007) yang mengemukakan bahwa konstruksi alat sangat mempengaruhi keefektivitasan rajungan dalam menemukan dan memasuki mulut bubu. Pada alat tangkap sebelum modifikasi rajungan berusaha mendekati alat dengan mengikuti bau dari umpan yang terbawa arus dan rajungan berusaha masuk melalui sisi alat hingga menenmukan pintu masuk atau rajungan tersebut gagal menemukan pintu masuk. Pada alat sesudah modifikasi, rajungan mudah untuk menemukan mulut alat karena terdapat pada 4 sisi yaitu kiri, kanan, depan dan belakang sehingga memudahkan rajungan untuk menemukan pintu masuk.

\section{KESIMPULAN}

Berdasarkan dari hasil penelitian modifikasi alat tangkap rajungan, dapat diperoleh kesimpulan sebagai berikut :

a. Pada trip pertama maupun trip kedua jumlah tangkapan rajungan tertinggi diperoleh pada perlakuan modifikasi alat yaitu masing-masing $10: 5$ dan $7: 4$.

b. Modifikasi alat tangkap rajungan dapat meningkatkan produksi rajungan. Dimana alat sebelum modifikasi menghasilkan produksi hanya $350 \mathrm{~g} / 14$ hari sedangkan alat sesudah modifikasi menjadi $627 \mathrm{~g} /$ 14 hari..

\section{DAFTAR PUSTAKA}

Amtoni $Y, A$,. Iriana $D$ \& Herawati $T$,. 2010. Pengaruh Perbedaan
Jenis Umpan Terhadap Hasil

Tangkapan Rajungan (Portunus pelagicus) Dengan Bubu Lipat Di Perairan Bungko, Kabupaten Cirebon, Fakultas Perikanan Dan IImu Kelautan Unpad.Jurnal Perikanan dan Kelautan. 1 (1) : $24-31$.

BPPMHP. 2000. Perekayasaan Teknologi Pengolahan Limbah. Jakarta : Direktorat Jenderal Perikanan.

Dollu, A. E. (Ed.). 2013. Modifikasi Konstruksi Bubu Dasar yang Dioperasikan Pada Perairan Warsalelang Kabupaten Alor Provinsi. Skripsi tidak diterbitkan. Makassar :Program Studi IImu Perikanan Program pasca sarjana Universitas hasanuddin

Ernawati, T. 2013. Dinamika Populasi dan Pengkajian Stok Sumberdaya Rajungan (Portunus pelagicus) di Perairan Kabupaten Pati dan Sekitarnya.Skripsi tidak diterbitkan.Bogor : Program Pacsa Sarjana Institut Pertanian Bogor.

Josileen J. 2011a. Food and Feeding of The Blue Swimmer Crab, Portunus pelagicus (Linnaeus, 1758) (Decapoda, Brachyura) Along The Cosat of Mandapam Tamil Nadu India. Crustaceana 84 (10):1169-1180.

Lismawati, D. 2005. Perbandingan Hasil Tangkapan Keong Macan antara Bubu Karang Serang dan Pelabuhanratu. Skripsi tidak diterbitkan. Pemanfaatan 
Sumber Daya Perikanan.

Fakultas Perikanan dan IImu Kealutan. Bogor: Institut Pertanian Bogor.

Miller, R.J. 1995. Option For Reducing Bycatch in Lobster and Crab Pots. Can. Dept of Fish and Oceans.

Muldiani, D . 2007. Analisis Hasil Tangkapan Rajungan pada Bubu Lipat dengan Konstruksi yang Berbeda di Perairan Kronjo, Kabupaten Tangerang. Dibimbing oleh Mokhamad Dahrilskandar. Skripsi tidak diterbitkan. Bogor. Department Pemanfaatan Sumber Daya Perikanan Fakultas Perikanan dan IImu Kelautan Institut Pertanian Bogor.

Nishida AK, Nordi N, Alves RRN. 2006. The Lunar-tide Cycle Viewed by Crustacean and Mollusc Gatherers in The State of Paraiba, Northeast Brazil and Their Influence in Collection attitudes. Journal of ethnobiology and Ethnomedicine. 2:1. doi:10.1186/1746-4269-2-1.

Robinson CJ, Gomez-Aguirre S. 2004. Tidal Stream Use by The Red Crab Pleuroncodes planipes in Bahia Magdalena, Mexico. Journal of Experimental Marine Biology and Ecology. 308:237252. doi:10.1016/j.jembe.2004.03.00

Sumpton, W. 1993. Australian Fisheries Resources.

http://www.edaff.gov.au/nfpd/atla s/28911005.cfim ( Diakses 8 Juli 2016).

Stergiou, K.J, Moutpoulas, D.K. and Erzini, K. Gillnet and Longline Fisheries in Cyclades Water (Aegean Sea) : Species Composition and Gear Competition. Fish. Res. 2002. 57 : $25-37$.

Tiyoso, S.J. 1979. Alat-Alat Penangkapan Ikan yang Tak Memungkinkan Ikan Kembali (Non-Return Traps). Karya Ilmiah (Tidak dipublikasikan). Fakultas Perikanan. Institut Pertanian Bogor. 